\title{
A development module of chemistry learning based on chemo- entrepreneurship oriented
}

\author{
Warni Arfin', Latisma ${ }^{2}$, Budhi Oktavia ${ }^{3}$ \\ ${ }^{123}$ Univeristas Negeri Padang, Padang - Indonesia, (warniarifin.it@gmail.com)
}

\begin{abstract}
Chemo-entrepreneurship has been used as a contextual learning in chemistry and it can be used to study the material processing into a product of economic value. The aim of this research was to produce teaching material in the form a chemistry module based chemo-entrepreneurship oriented for grade XI students on the odd semester. The research and development approach was used in this study. The data were collected through interviews, observations, and questionnaires. The result of the analysis showed the validation score of the module as very valid. Practicality tests based on student and teacher responses have shown that positive response toward module of chemoentrepreneurship oriented. The effectiveness test module has been done based on student learning outcomes and showed effective category. In conclusion, the finding showed the module based chemo-entrepreneurship oriented for chemistry learning as valid, practical and effective for use in grade XI students on the odd semester.
\end{abstract}

Keywords: development research, chemistry learning, chemo-entrepreneurship

\section{Introduction}

Chemistry has become a field of study that plays an important role in the advancement of science and technology. Chemistry is a part of natural science that studies the structure, properties of substances, changes in matter, and the energies involved, laws, principles and theories. One of the competencies in learning chemistry is to analyze and solve problems related to chemical concepts, and apply the knowledge gained in science and technology .The application of technology in chemistry learning has been possible on creative projects to produce entrepreneurial-oriented products. The introduction of entrepreneurial learning in science has been able to produce sustainable technological growth. Knowledge relating to chemistry has been very helpful in increasing the production of a product these can be transformed into a business plan through learning oriented entrepreneurship. Entrepreneurship-oriented chemistry learning is also known as chemo entrepreneurship, abbreviated as CEP . CEP is a contextual learning approach that is associated with real objects or phenomena around human life, and then this has given the opportunity to learners to learn the processing of a material into a useful product and economic value. This approach has been able to provide innovation in orienting and developing creative ways learners in integrating chemistry to entrepreneurship so as to motivate and foster entrepreneurial interest of learners . 
This approach has made learning chemistry more interesting and fun.Chemoentrepreneurshiporiented learning has provided a hands-on learning experience to learners about the usefulness of chemistry for individuals, communities, and the environment. It has been accomplished in this regard; the purpose of chemistry education is to ensure that every learner gains a good understanding of science then in order to apply it in everyday life .

Observations have been carried out by researchers in three High Schools at Padang city (SMAN 1, SMAN 5, and SMA 1 Pertiwi). It found that chemo entrepreneurship-oriented chemistry resources have never been available in those schools.In generally, worksheets and textbooks as teaching materials have used. Some teachers have rarely used the module as teaching material because it is not available in school yet.The results of interviews with teachers have shown that teachers have not yet introduced chemo entrepreneurship learning to students, thus causing lessons to be delivered yet to lead to the application of chemical concept knowledge to produce products related to everyday life. In addition, practical activities those have been implemented only to the investigation and proof of concept, while the application of chemical knowledge to produce products itself has never existed in practice so this has caused not to grow interest and entrepreneurship spirit of students. The result of the observation questionnaire of the students has shown that learning chemistry will be very interesting and useful for the students; if the teaching materials used are also equipped with the application of knowledge of chemistry to process a material into a useful product and economic value so that learners can utilize the knowledge of chemistry to have entrepreneurship. Entrepreneurshiporiented learning has been able to provide entrepreneurship training through small projects to students. Therefore the development and manufacture of teaching materials in the form of chemo entrepreneurship oriented chemical modules as a means and learning resources needs to be done.

Chemo entrepreneurship-oriented chemistry module is a printed or written media systematically composed of real life-related content and is equipped with the application of chemical knowledge to process a material into a useful and economic value product.Presentation of materials in the chemo entrepreneurship oriented module is expected to lead students to find ideas and information by applying the knowledge gained to science and technology. Chemistry learning material of grade XI odd semester has very appropriately developed with this approach; it is based on the number of conceptual learning that can be applied in the manufacture of products. The material consists of five subjects, namely hydrocarbons, petroleum, thermochemical, reaction rates and equilibrium.The developed modules could provide a learning experience directly to learners about the usefulness of chemistry for individuals, communities, and the environment. The module has provided an opportunity for learners to learn the processing of a material into a useful product and economic value, so that learners can use their knowledge of chemistry to entrepreneurship and can motivate and foster entrepreneurial interest for learners in the learning process such as creative, innovative, insightful, independent and never give up .

This research has aimed to produce module based on chemo entrepreneurship oriented which is valid, practical and effective to enable students for understand the odd semester chemistry materials as well as to foster students entrepreneurship interest.

\section{Method}

Research and Development (R \& D) methods have been used in this study. Research development is the research used to produce a particular product and test the effectiveness of the product. The Plomp model as a development design has been used. This model consists of three stages: (1) preliminary research stage. (2) Phase prototyping phase. (3) Phase assessment phase.

Data collection instruments used were interviews; it used as problem identification and requirement, self-evaluation sheet;it used to check the completeness of module components and module compilation errors, validity sheet;it used to know module validity, practicality questionnaire sheet; it used to know teacher and student response regarding module, observation sheet; it used to 
observe participant activity students and test results; it used to identify outcome changes in learning after using chemo entrepreneurship oriented module.

Quantitative descriptive techniques have been used as an analysis of this study. The success indicator of chemo entrepreneurship oriented chemistry learning module development is valid if the percentage of validation score is at least $61 \%$. The module is effective if the students' learning outcomes are at least $75 \%$ above the KKM (minimum completeness criteria) and student learning activities during the learning process takes at least $61 \%$ in the high criteria. In addition chemo entrepreneurship oriented chemistry learning modules will have received practical responses from users (teachers and students).

\section{Results and Discussion}

The research result of chemo entrepreneurship oriented chemistry learning module include: 1) Result of problem analysis and needs; 2) The validation result of the chemo entrepreneurship oriented module (CEP) by the validator; 3) Practicality test results (teacher and student response); 4) The effectiveness of chemo entrepreneurship oriented module (CEP) towards understanding students' concepts and learning activities.

Based on the results of interviews with chemistry teachers have revealed that teaching materials used by teachers are text books and student worksheets. Most teachers still rarely use the module in the learning process, because the teaching materials in the form of modules not yet available in the school. Furthermore, the available teaching materials have not reached the application of chemical concept knowledge to produce useful products and economic value. In addition, practical activities carried out only until the investigation and proof of the concept alone so that the available teaching materials have not been able to motivate and foster entrepreneurial interest of learners. Teachers and learners expect the teaching materials in accordance with the basic competence requirements that have been established. Technically, the thing that is delivered first is a concept that must be understood in addition to it followed by its roles in everyday life.

In teaching materials, there is application of chemical concept knowledge to produce useful products and economic value. Teaching materials will be able to attract learners to learn, facilitate the implementation of learning and can provide entrepreneurship training through small projects to learners in learning chemistry, motivate and foster entrepreneurship interest of learners by learning by applying and doing skills training, it can help in growing entrepreneurial skills in learners [14]. Therefore the development and manufacture of teaching materials in the form of chemo entrepreneurship oriented chemistry learning module as a means and learning resources needs to be done.

Chemo entrepreneurship-oriented chemistry module was a printed or written media systematically composed of the items that was linked to real life and equipped with the application of knowledge of chemistry to process a material into a useful product and economic value.

Design and preparation chemoentrepreneurship oriented chemistry module based on reference module preparation. The module consists of cover, introduction, entrepreneur character and chemical application in entrepreneurship, module usage manual, occupational health and safety, core competence, basic competence, competency achievement indicator, learning objective, student worksheet, chemoentrepreneurship activity sheet, test sheets, answer keys, conclusions, and bibliography. The developed module has been designed with Microsoft Word 2007.

After designing and manufacturing phase, the next stage was self-evaluation. This stage focused on the completeness of the chemoentrepreneurship oriented chemical module component. The evaluation results showed that the module components already exist and accordingly. However, 
there was some errors letters were not complete so the meaning becomes unclear, the error wrote of the tool functions used in practical activities and error chemoentrepreneurship work procedures presented in the module. After evaluation, revision is made by improving incomplete writing and improving the function of equipment and improving the chemoentrepreneurship work procedure prior to the expert review of chemoentrepreneurship oriented chemistry learning module.

The validity of chemoentrepreneurship-oriented chemistry learning modules has been taken on the basis of expert judgments covering four aspects of construct, content, graphics, and language aspects. Validation has been done by five expert validators. In addition to assessing the module, the validator is also required to provide suggestions for improvements to the module. The suggestions provided by the validator are then used as a reference to revise the developed module.

Data validation results oriented chemoentrepreneurship chemistry learning modules are presented in Table 1.

Table 1. Test Results Validity of chemoentrepreneurship oriented chemistry module

\begin{tabular}{llcl}
\hline No & Aspect Assessed & Average percentage $(\%)$ & Categories \\
\hline 1 & Content compound & 85,2 & Very valid \\
2 & Construct compound & 81,1 & Very valid \\
3 & Language compound & 83,3 & Very valid \\
4 & Graphical compound & 87,7 & Very valid \\
& Average & 84,3 & Very valid \\
\hline
\end{tabular}

Table 1 revealed the assessment of chemoentrepreneurship oriented modules based on content, constructs, language and graphical contents met the valid category with a validation score of more than $61 \%$. So the module can be used for field trials. In the module validation stage, the validator provided input: (a) clarify and enlarge the image size; (b) fixing elusive phrases and writing too long titles; (c) correcting the concept and spelling errors in the module. The module is then revised in accordance with the validator's suggestion before a one-to-one trial.

After the validity test by expert, one to one test is conducted on three heterogeneous learners. In one-on-one trials, informal interviews were conducted with the learner to ask the students' feedback and suggestions on the developed modules, and then the practicality test was done to find out the benefits, ease of use, attractiveness and time efficiency of developed modules.

Based on the results of interviews have obtained the results of cover and color choices.It could provide attraction to students in learning. In terms of both the material and language presentations used were good and detailed and used language that was easily understood by the students. In addition, the pictures displayed in the module could make it easier for students to find their own concepts. The steps contained in the module were also easy to understand by students and chemoentrepreneurship activities in the module can motivate and foster student entrepreneurship interest.

The result of the experimental data of chemoentrepreneurship oriented chemistry experiments could be seen in Table 2 .

Table 2. The results of one-to-one chemoentrepreneurship-oriented chemistry experiments

\begin{tabular}{llcl}
\hline No & Aspect Assessed & Average percentage $(\%)$ & Categories \\
\hline 1 & Ease of use & 81 & Very practical \\
2 & Attractiveness & 80 & Practical \\
3 & Efficiency of usage time & 80 & Practical \\
4 & Benefit of use & 77 & Practical \\
& Average & 79 & Practical \\
\hline
\end{tabular}


Table 2 discloses the overall results of chemically oriented chemistry practice chemistry oriented learning module. In one-on-one trials it has met the practical category with a score of $79 \%$.After small group testing, the next stage of development is small group evaluation. This small group evaluation has been done by explaining the steps of chemoentrepreneurship oriented module. Learning for a single meeting of six students has been implemented. The result data of small group chemoentrepreneurship oriented chemicals experiment can be seen in Table 3.

Table 3. The results of the experimentation of small group chemoentrepreneurship-oriented chemistry module

\begin{tabular}{llcl}
\hline No & Aspect Assessed & Average percentage (\%) & Categories \\
\hline 1 & Ease of use & 84 & Very practical \\
2 & Attractiveness & 77 & Practical \\
3 & Efficiency of usage time & 86 & Very practical \\
4 & Benefit of use & 80 & Very practical \\
& Average & 81 & Very practical \\
\hline
\end{tabular}

Overall, the results of module practice in small group trials were $81 \%$ in very practical categories. This revealed that chemoentrepreneurship oriented chemistry module for grade XI SMA/MA students could be used for field test. Yet there were still some parts that need to be fixed. After the revision of small group test results according to the suggestions and comments of learners, then its carried out the next stage of development was test field test to get results about the practicality and effectiveness chemoentrepreneurship oriented chemistry module generated. At this stage, learning activities are conducted using a revised chemoentrepreneur-oriented module. Learning activities begunby pretest, practical activities, group discussions, product planning related to hydrocarbon material, petroleum, thermochemistry, reaction rate and chemical equilibrium. Field test aimed to determine the effectiveness of modules that have been designed, module effectiveness criteria could be seen from the influence of the use of modules on learning outcomes and activities of learners. Here was the result of data analysis about the effectiveness of modules that have been used.

\section{Student activity}

Student activity was one of the aspects used to see the effectiveness of the developed module. Assessment of student activity has been done at each meeting. The student's activity assessment categories were consist of reading, viewing illustrations, observing experiments, asking questions, collecting information, responding to questions, listening to discussions, recording test results, recording the results of discussions, working on worksheets, doing exercises, discussing, taking notes, demonstrating the results of the discussion in front of the class, experimenting and excited in doing chemoentrepreneurship practice.

The result of observation of the students activity obtained by the percentage value of the student activity when using chemoentrepreneurship oriented module was $80 \%$, which showed that during learning to use chemoentrepreneurship oriented chemistry module many students were actively involved. Based on student activity revealed the student has done every activity that already exist in module. Student exercises and worksheets on the module couldbe answered by students and the also practice activity to produce the product has been done well. The products that students have produced were briquettes, aromatherapy candles, gel compresses, Styrofoam cooler box, and coconut oil also baking soda toothpaste. It was revealed that during the study using chemoentrepreneurship oriented chemistry module many students are actively involved.This has revealed the delivery of messages to modules was well understood for use in studying the chemistry of the odd semester grade XI.

\section{Student learning outcomes}

The effectiveness test of the developed module can be seen from the change of students' learning result before (pre-test) and after (post-test) using the developed product. The purpose of pre-test was 
only to see the initial ability of students before learning to use products developed. Learning outcomes of students can be seen in Table 5 below.

Table 4. Student learning outcomes

\begin{tabular}{lccc}
\hline & \multicolumn{2}{c}{ Completeness } & Total \\
\cline { 2 - 3 } & Completed & Uncompleted & \\
Students total & $(\geq 71)$ & $(<71)$ & \\
Percentage & 27 & 4 & 31 \\
\hline
\end{tabular}

Student learning outcomes after using chemoentrepreneurship oriented chemistry module that was $>87 \%$ of students above the minimum completeness criteria. It revealed that the effectiveness of chemoentrepreneurship oriented module was in good category. So it was concluded that the module has been effective to be used as a learning resource in the learning process.

\section{Practicality based on student and teacher response questionnaires}

Practicality data has been obtained based on the teacher and student response assessment sheets. Questionnaire has been filled by the teacher as a purpose to get information about module practicability based on teacher consideration. The results of the questionnaire responses obtained by the average value of module practicality were $88 \%$ in the practical category.Practicality test based on student response questionnaire has been done by getting the learning process using the developed module as well as predetermined schedule. Practicality test was done by giving questionnaires of practicality to students after using chemical module oriented chemoentrepreneurship.Practicality data on field test chemoentrepreneurship oriented chemo field test can be seen in Table 5 .

Table 5. The results of practicality as a field test chemoentrepreneurship-oriented chemical module test.

\begin{tabular}{llcc}
\hline No & Aspect Assessed & Average percentage (\%) & Categories \\
\hline 1 & Ease of use & 90,6 & Very practical \\
2 & Attractiveness & 94,3 & Very practical \\
3 & Efficiency of usage time & 95,1 & Very practical \\
4 & Benefit of use & 91,3 & Very practical \\
& Average & 90,8 & Very practical \\
\hline
\end{tabular}

Table 5 revealed the practicability of chemoentrepreneurship oriented modules based on student responses as score as more than $61 \%$.

In terms of ease of use, the developed module has facilitated teachers in implementing and achieving learning goals and could help teachers to motivate and foster entrepreneurial interest in learners.Based on aspects of time efficiency and benefits, the implementation of learning using chemoentrepreneurship-oriented module has leaded to more efficient learning.The learning materials could be benefited by learners in the structure of science and everyday life. Interest or considerable student attentiveness could occur hence by students asexcitedas experience that students got and the applications of the knowledge they acquire in their daily lives, so as to foster students' interest, motivation, and curiosity. This was in accordance with the findings of Haryati (2012), students who have been accustomed to produce useful products and economic value in everyday life could increase interest and motivation in learning and entrepreneurship. Skills training in learning also could help foster entrepreneurship skills in learners [10],[4].From all aspects assessed the module obtained a good response score, means chemoentrepreneurship oriented module could be received well and used as a teaching material in studying chemistry grade XI on the odd semester. 


\section{Conclusions}

Based on the development and tested, the developed chemoentrepreneurship module was valid or feasible to be used as a learning resource as $84.3 \%$ categorized as very valid.The percentage of student learning activity measured as effectiveness has been obtained on average $80 \%$ as effective category. While the effectiveness of the module based on student learning outcomes, it obtained an average of $87 \%$ categorized as effective. In addition, practicality based on student and teacher responses showed their positive responses to the developed modules which categorized as practical, so the module could be well received and used as a teaching material in studying chemistry grade XI semester odd.

\section{Acknowledgments}

I am very pleasedto IbuLatisma, and Budhi Oktavia, both parents, colleagues at UniversitasNegeri Padang, teacher and students at SMAN 1, SMAN 5, and SMA 1 Pertiwi at Padang who has helped this study.

\section{References}

Chang, Raymond. (2010). General Chemistry: The Essential Concept Third Edition. New York: McGrew Hill Higher Education.

Permendikbud. (2016). Standar Isi Pendidikan Dasar dan Menengah. Jakarta: Badan Standar Nasional Pendidikan.

American Chemical Society. (2012). ACS Guidelines and Recommendation for the Teaching of High School Chemistry. Washington: Society Committee on Education.

Bilya Abdu. (2010). Chemistry Education and Entrepreneurial Development in Nigeria.Department of ChemistryFederal College of Education, Katsina

Runge Wolfgang and Stefan Bräse.(2011). Education in Chemical Entrepreneurship: Towards Technology Entrepreneurship for and in Chemistry-Related Enterprises. Germany and Institute of Organic Chemistry, University of Karlsruhe (TH) and Karlsruhe Institute of Technology (KIT). Germany.

Agustin, RisqiLiadan Sri Poedjiastoeti. (2014). PengembanganLembarKegiatanSiswa (LKS) BerorientasiChemoentrepreneurshipuntuksiswa SMA.Unesa Journal of Chemical Education, volume III, nomor 2.pp. 116-117.

Gladys Uzezi Jack and Dimas Jen Blessed. (2015). Promoting Entrepreneurship Opportunities through Chemistry Education A Path to the Empowerment of Nigerian Youths for Sustainable Development in the 21st Century,InternationalJournal of Research and Development (IJRD), Volume II. No 1, pp. 515.

Sugiyono. (2012). Metode Penelitian Pendidikan Pendekatan Kuantitatif, Kualitatif, dan R \& D. Bandung: Alfabeta

Plomp, T. and Nieveen N. (2013). Part A: Educational Design Research: An Introduction. Netherland: Netherland Institute for Curriculum Development (SLO).

Haryati, Sri. (2012). "PengelolaanPembelajaran Kimia Berbasis Chemoentrepreneurship di SMA Negeri 1 Kartasura".NaskahPublikasi, pp. 2-4

Ogunleye, A. O. (2007). Building a sustainable science curriculum in Nigeria: Accommodating local adaptation, levering technology and enhancing areas of improvement for quality assurance. STAN Proceedings of the 50th Anniversary Conference, pp.36-44. 